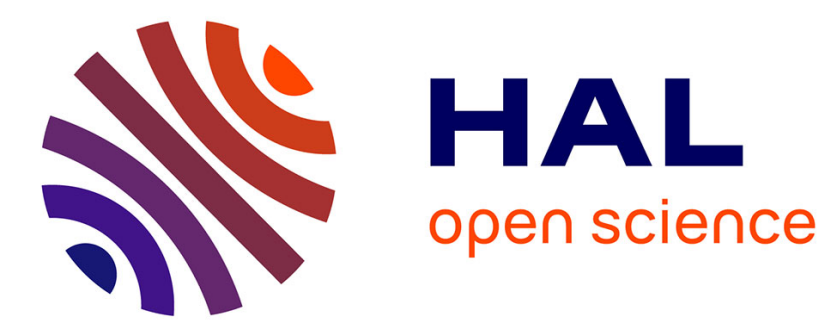

\title{
Iraqis in exile: Migratory networks as a coping strategy Kamel Dorai
}

\section{To cite this version:}

Kamel Doraï. Iraqis in exile: Migratory networks as a coping strategy. International Journal of Contemporary Iraqi Studies, 2011, 5 (2), pp.215-229. 10.1386/ijcis.5.2.215_1 . halshs-00660141

\section{HAL Id: halshs-00660141 https://shs.hal.science/halshs-00660141}

Submitted on 25 Mar 2014

HAL is a multi-disciplinary open access archive for the deposit and dissemination of scientific research documents, whether they are published or not. The documents may come from teaching and research institutions in France or abroad, or from public or private research centers.
L'archive ouverte pluridisciplinaire HAL, est destinée au dépôt et à la diffusion de documents scientifiques de niveau recherche, publiés ou non, émanant des établissements d'enseignement et de recherche français ou étrangers, des laboratoires publics ou privés. 


\title{
Iraqis in exile:
}

\section{Migratory networks as a coping strategy}

\author{
Mohamed Kamel Doraï
}

\begin{abstract}
The largest concentration of Iraqi refugees is in Syria. Here they are treated officially as 'guests', having no formal legal status. Facing increasingly difficult circumstances, increasing numbers of refugees attempt to move to third countries. Using research undertaken in Syria and Sweden, this article examines the pressures that lead them to undertake new journeys and the means by which they mobilize kin and religious networks.

IRAQI - REFUGEES - SYRIA - SWEDEN - MIGRATORY NETWORKS -

RELIGIOUS NETWORKS - RESTRICTIVE ASYLUM -

TRANSNATIONALISM - LOCAL INTEGRATION - FAMILIAL DISRUPTION
\end{abstract}

Since 1991 Iraqis have been emigrating en masse from their homeland to neighbouring countries and further abroad. The fall of Saddam Hussein's regime in 2003 accelerated the outflow of refugees, mainly due to insecurity and the rise of sectarian violence. Both the departure context in Iraq and the emigration process in transit and receiving states have led to the development of family-based and/or religious-based networks. At the same time, sectarian violence has deeply changed the geography of Baghdad, where the majority of refugees originate, leading to forms of religious homogeneity of certain neighbourhoods. This has contributed to the reinforcement of a sectarian-based emigration process. Religious networks have played a key role in emigration since the events in Iraq in 1991 (Chatelard 2003; Danis 2006) and even before in relation to economic migration during the 1970s. For many Iraqis, the use of transnational networks is linked to problems of access to local resources both in the country of origin and in transit countries, due to generalized violence in Iraq or socio-legal restrictions in the latter. Sectarian violence, parallel to the rising sectarian divisions of the post-2003 Iraqi social and political spheres, has contributed to the development of religious-based networks as a key resource for migrants. Restrictive asylum policies in most European countries also contribute to the development of strategies that aim to circumvent these restrictions. Iraqi refugee families are typically scattered across a number of

\footnotetext{
* Chargé de recherche au CNRS, MIGRINTER, UMR 7301, département de Géographie, Université de Poitiers
} 
countries; family and community networks may be dislocated but at the same time they may preserve intra-familial cohesion.

Due to the massive exodus, Iraqi families and Iraqi communities have to reorganize in exile. Recent geographical scattering of some families and groups in different countries, and in different locations in the same country, has generated ruptures in the networks. The gap between households with strong local and/or transnational connections and those who do not have access to resources and mobility is increasing with the duration of exile. This article is based on fieldwork in Damascus and Beirut and preliminary fieldwork in Stockholm. After presenting an overview of Iraqis in Syria, I examine the role of religious-based networks - mainly those of Assyrians and Chaldaeans - as part of the emigration process and consider interactions with family networks.

Since the beginning of the twentieth century Syria has hosted refugee groups such as Armenians, Palestinians and more recently Lebanese escaping the war of 2006. Like most of the countries in the region, Syria is not a signatory to the 1951 Convention or the 1967 Protocol, and there is no specific memorandum of understanding between UNHCR and the Syrian authorities. The recent migration of Iraqis to Syria has its own specificities: there was no mass exodus in one or two waves, such as in the Palestinian case in 1948, but a growing influx of individuals and families crossing borders with Iraq. From 2003 Syria had an open-door policy towards Iraqis, whom the government views as Arab citizens and whom it has not attempted to expel. In October 2007 measures to restrict entry of Iraqi refugees were implemented, however. Refugees have access, with some restrictions, to public education and health services. All are located in urban areas - no refugee camps exist, except for those accommodating a few hundred Palestinians from Iraq, who have been settled in three sites on the Iraqi border. One of them, Al Tanf, closed in February 2010, while Al Hol camp in Syria still holds more than 400 Palestinians (UNHCR 2010). A UNHCR report of 2003 recalls the situation of Iraqis in Syria before 2003:

The Iraqi refugees in the Syrian Arab Republic are mostly of Arab ethnicity, 70\% are Shias originating from the southern part of Iraq, around 15\% are Sunnis and the remainder are Kurds, Assyrians from Baghdad and Basrah, Turkomen from the Khanaquin region and Yazidis from the Sinjar area. Some 2,400 Iraqis have been granted or are being considered for refugee status by UNHCR. Furthermore, there are around 60,000-70,000 Iraqis who have never approached UNHCR or have been denied refugee status through the UNHCR refugee status determination process and continue to reside illegally in the country, tolerated by the Syrian authorities. Most Iraqis in Syria are concentrated in the Saida Zeineb quarter in Damascus located near prominent Shia shrines (2003: 6).

Since 2003, the situation has changed dramatically and Iraqis are now located in most Damascus suburbs and in neighbouring cities.

\section{GROWING IRAQI PRESENCE IN SYRIA}

Some attempts to restrict the entry of Iraqis in Syria have been implemented periodically. In 2007, the duration of the visa granted to the Iraqi citizens at the border was reduced to one month 
renewable (having previously been three months renewable). Since 11 September 2007 Iraqis wishing to enter Syria have been required to apply for visas, the measure being postponed and finally implemented on 1 October 2007. Only Iraqis entering the country for commercial, transport, scientific and education purposes have obtained visas since the implementation of this procedure (UNHCR 2007a; UN News Center 2007).

Some Iraqis have crossed Syria to travel to Lebanon but the number of Iraqis there remains low due to the strict entry regulation and the Lebanese government's policy of detaining illegal migrants. According to a report of the Frontiers Association in Beirut:

As Lebanon does not share borders with Iraq, there was no massive rush of Iraqis on the Lebanese borders. Most Iraqis pass through Syria before arriving in Lebanon [...]. At the end of 2005, the Lebanese General Security granted visas for Iraqis at all border points if Iraqis could provide the following: a return non-refundable ticket, a hotel reservation or the address and phone number of a person in Lebanon, and US\$2,000 in cash or in a bank account. Hence, Iraqis who fulfilled these conditions were admitted to Lebanon on temporary basis. Many Iraqis were unable to meet these conditions mostly because of financial reasons. As a result, most Iraqis are forced to enter Lebanon illegally in unsafe smuggling conditions and remain in illegality for the period of their stay. [...] Even those who were granted entry visa face difficulties when they wish to prolong their stay in Lebanon (2006: 19).

Living costs, difficulties obtaining residency rights and political instability in Lebanon are the main elements that explain the relatively low Iraqi emigration from Syria. Recently arrived Iraqis from northern Iraq, mainly from the Mosul region, have arrived in Beirut and they arrived directly by plane from northern Iraq, avoiding passage across Syria.

Karen Jacobsen comments that, '[t]he hidden, marginalized nature of urban refugees makes it difficult to make accurate estimates, and each "authoritative" source has its own agenda and set of reasons for the number it puts out' (2006: 275). It is difficult to evaluate the foreign population living in Syria. The Syrian census of population of 2004 indicated an Arab non-Syrian population of 88,566 people - Palestinians are not included - (Syrian Population Census 2004). Arab nationals can reside without requiring a residency permit: they obtain a three-month visa when entering Syria; when it expires they may extend for another three months but must then leave Syria and cross the border again to obtain a new three-month visa.

Syrian authorities, and the UNHCR and other international organizations, estimate the number of Iraqis in Syria at 1.2 to 1.4 million, an estimation which seems to be very high. As the vast majority do not hold a residency card but have tourist visas (in fact they are considered as 'guests'), the actual number of Iraqis in Syria is hard to assess (International Crisis Group 2008: 16; Leenders 2008: 103). In December 2005 a survey undertaken by the UNHCR, WFP and the UNICEF estimated the number of Iraqis at 450,000 (UNHCR 2006: 1). The Syrian authorities have recognized since the beginning of the conflict in Iraq that irregular migration is very difficult to control, even if the number of people apprehended for illegal residence remains very low - around 300 individuals per year (Simon 2006: 34). In September 2007 Syrian authorities confirmed that 
they would not deport Iraqi refugees. Nevertheless, as shown in the table below, the number of Iraqis registered by the UNHCR in Syria reached some 230,000 in 2008, declining since 2009. This figure probably corresponds to the actual number of Iraqis in Syria.

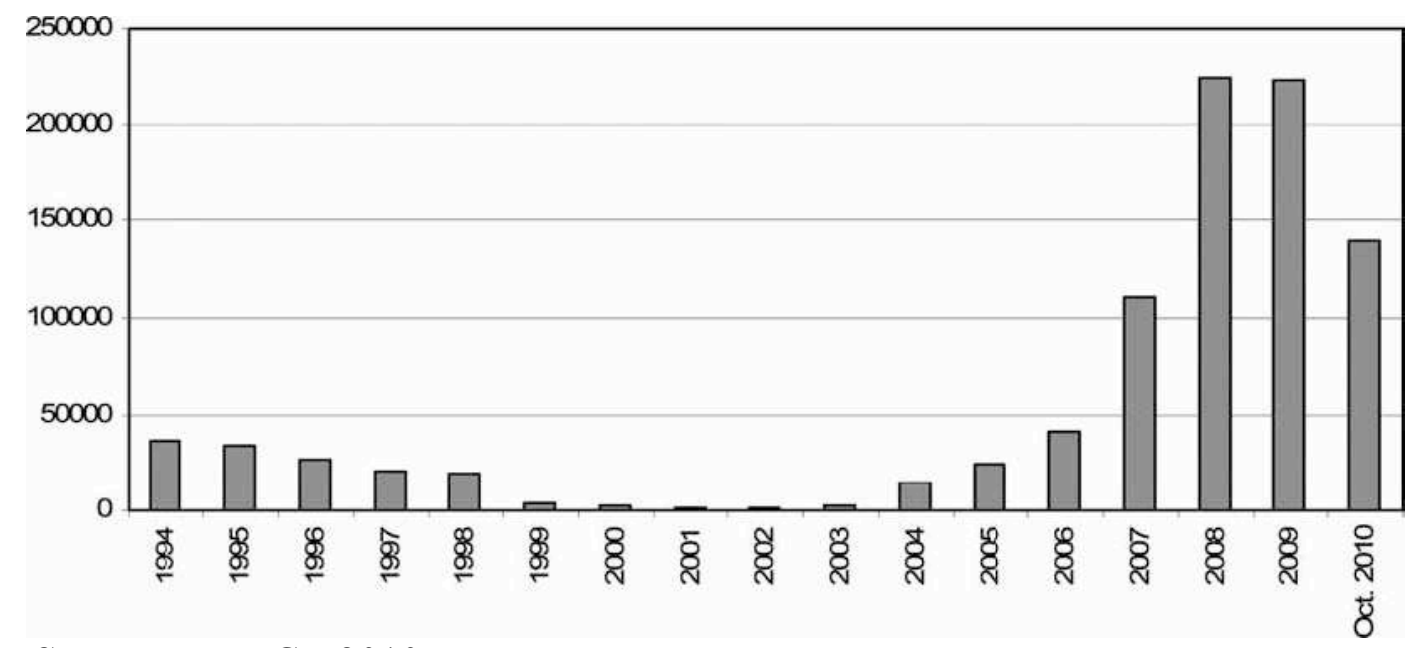

Source : UNHCR 2010.

Figure 1: Iraqis registered at the UNHCR (1993-October 2010).

The strong disparity in the estimates of the Iraqi refugee population is partly a result of means of categorization of Iraqi residents as well as political and economic opportunities. While the UNHCR registers 'refugees', the Syrian authorities do not recognize this status; rather, the agency counts Iraqi citizens. Some Iraqis in Syria may not consider themselves as refugees and/or do not consider themselves in need of assistance; hence, they do not register at the UNHCR - but these cases seems to be limited.

Asked why Iraqis 'chose' Syria as a host country, most of my informants provided one or more of the following explanations: that Syria was the only country accepting Iraqi refugees; that they already had family or close relations in Syria; that life in Syria was affordable (compared for example with the northern districts of Iraq); or that they could obtain access to school and partial access to the health system.

\section{REFUGEE STUDIES AND NETWORK ANALYSIS}

Network analysis provides an interesting framework that goes beyond juridical approaches imposed by the term 'refugee' and its meanings in international law. The Iraqi experience is a good illustration of this. Nadje Al-Ali notes that the Iraqi diaspora has developed since the 1970s and should be understood in the context of a diverse migratory setting:

Iraq is a case in point, presenting a continuum of economically driven migrants, especially under economic sanctions (1991-2003) which were part of a political crisis together with political refugees fleeing the persecution, torture and 
repression of the dictatorship of Saddam Hussein (1979-2003). This is in the context of a longer history of various forms of migration - for education, labour and from persecution well before the rise of the Ba'th (2007: 139).

A huge diversity of social, legal and economic statuses and personal backgrounds coexists inside the formal category 'Iraqi refugee'.

Early attempts to build a general theoretical model on refugee issues focused mainly on push factors (e.g. Kunz 1973, 1981). More recent studies have emphasized the role of international relations in the production of refugee flows (e.g. Loescher 1990; Weiner 1993). Little attention has been paid to the dynamics generated by the refugees themselves, however. The duration of exile and the different kinds of interaction with host societies have also generated varying forms of mobility. Richmond stresses that:

[...] the distinction between free and forced or voluntary and involuntary is a misleading one. All human behavior is constrained. Choices are not unlimited but are determined by the structuration process. However, degrees of freedom may vary. Individual and group autonomy and potency are situationally determined. It would be more appropriate to recognize a continuum at one end of which individuals and collectivities are proactive and at the other reactive (1994: 55).

Network analysis of migration is a growing field of interest (Durand 1994; Fawcett 1989; Kritz and Zlotnik 1992; Massey et al. 1993) $)^{1}$. Thomas Faist (2000) observes that the analysis of migration in terms of migratory networks suffers from one main limitation: it does not tackle the question of the emergence of such networks. He considers that initially social capital ${ }^{2}$ is a factor that limits mobility; then, when migratory networks develop, it becomes a driving force of emigration. This analytical framework aids the understanding of Iraqi migra-tory dynamics from the Middle East to Europe. Since the 1970s many Iraqi refugees and migrants have emigrated to northern Europe. Forms of solidarity have developed in a transnational migratory field (Simon 2000), which supports and accelerates the emigration process. Faist notes that the installation of earlier migrants is a central element that permits the development of migra-tory networks because they 'condense' social capital (2000). Migration develops when social capital does not function only on a local scale, but also as a transnational transmission belt. Earlier Iraqi migrations helped to determine the present polarization of flows towards specific locations (such as Sweden, Australia, the United States, etc.), consolidating the central role of family networks.

\footnotetext{
${ }^{1}$ For a synthetic approach to network analysis related to migration see Ma Mung et al. (1998: 12).

2 Thomas Faist comments: 'Social capital denotes the transactions between individuals and groups that facilitate social action, and the benefits derived from these mechanisms. It is primarily a local asset and can be transferred cross-nationally only under specific conditions' (2000: 15).

3 'Le champ migratoire est, ici, défini comme l'ensemble de l'espace structuré par les flux migratoires et relationnels, espace parcouru, pratiqué, vécu par les populations migrantes'/'The migratory field is defined as the whole space structured by migratory and relational flows, a space that is traveled through, frequented, lived by the migrant's population' (Simon 2000).
} 
In recent years there has been growing interest in the relations between refugees and transnationalism (Shami 1996; Al-Ali et al. 2001; Black 2001; Koser 2002; Wahlbeck 2002). Studies of refugees' transnational activities have contributed to analysis of the role of the state in shaping migrants' networks, bringing the state back into most analyses. Black comments: 'Focusing on the role played by refugees in transnational activities could help to dispel some of the more idealistic notions of transnationalism from below as a people-led process, which take advantage of processes of globalization and ease of travel in the modern world' (2001: 66).

For many Iraqis, the use of transnational networks is linked to their problems of access to local resources both in the departure country and in the transit countries (mainly Syria and Jordan) due to generalized violence in Iraq or socio-legal restrictions in transit countries. Sectarian violence, parallel to the rising sectarian divisions of the post-2003 Iraqi social and political spheres, has contributed to the development of religious-based networks as a resource. In addition, asylum policies in most of the European countries have encouraged the development of strategies that aim to circumvent restrictions on entry. Family and/or religious networks often appear as the only available resource to emigrate.

\section{KINSHIP NETWORKS AND RELIGIOUS AFFILIATION}

Many authors have examined the relations between migratory networks and kinship, notably those concerning 'economic' migrants such as Algerians in France and family reunification in western countries (Montagne 1954; Choldin 1973; Katuszewski and Ogien 1981; Boyd 1989; Fawcett 1989). Some researchers in the Refugee Studies field have also pointed out the importance to host countries of family networks in processes of adaptation of forced migrants (e.g. Hansen 1981). In the Iraqi case, transnational migratory networks play a significant role in four principal fields: collection of the funds necessary to emigrate; 'family reunification' migration strategies; information flow between country of destination and country of departure; and adaptation of newcomers and/or the returnees. Minorities such as Christians or Mandaeans are over-represented in the registered refugee group, partly due to the efficiency of their migratory networks and the presence of diasporic links with western countries. As Van Hear notes, access to transnational networks and mobility becomes central in the development of coping strategies:

Still other extended family may go abroad as labor migrants, asylum seekers, undocumented workers, or through other migratory channels to find work or incomes for themselves and the family. Such 'strategies', if they may be called this, may well be in place before displacement, but the port folio of strategies is likely to be broader after displacement, sometimes of necessity, sometimes by new opportunities opening up. Access to social networks and mobility can be among refugees' most important assets.

(2006: 12)

The earlier Iraqi presence in Syria may explain in part the pattern of movement of Christians or Shi'a Muslims, although my informants seem to rely more on kinship networks than on religious networks. The scale of movements since 2006 seems to have exceeded the network's capacity to assist families and individuals. Nevertheless, pre-2003 migrants seem to have had an important 
impact on the geographical location of Iraqi religious groups in the Damascus urban area. Certain groups such as Assyrians try to reorganize themselves locally and to gather in certain neighbourhoods such as Jaramana, close to their church and other institutions. They try to recreate in exile forms of local solidarity that operate as a coping strategy.

Following the Gulf War of 1991, Jordan was the main destination state for refugees from Iraq and a space of transit for more than 500,000 Iraqis who found refuge worldwide (Chatelard 2003). Today, Syria plays a similar role because of its flexible migratory policy, even if entry and residence policies have been tightened since October 2007. Among refugees, relations with Iraq remain strong, with many taxis, buses and trucks travelling between Damascus and Aleppo and the main Iraqi cities. The last episode of violence in autumn 2008 against the Christian Iraqis in Mosul led to the arrival of several hundred families in Syria.

Solidarity networks play a significant role in the organization and the development of the Iraqi exodus, in both the country of departure and the host country. Their action is associated with various stages of the migratory process: they permit the mobilization of the funds necessary for the trip; they provide information on the country of destination; they facilitate adaptation of newcomers in the host country; they play a role in selection of the migrant from the departure country to fit the specific needs of host country; they help to circumvent legal constraints in the host countries; and they influence the destination location of migrants (Gurak and Caces 1992; Boyd 1989; Light 1993).

Most families interviewed in Damascus have members of their close family settled abroad, countries cited most often being Australia, the United States, Sweden and Germany. Some family members receive remittances from close relatives who have been settled for a long time in their host country; many, however, arrived recently and are in the process of regularization or live solely on social welfare. This greatly limits their capacity to send money to help members of their family in Syria. Even when remittances are sent, they barely cover rental expenses: typically they amount to between US\$100 and US\$200 per month: this rarely allows a family to live.

\section{REFUGEE NARRATIVES}

I conducted interviews in Södertälje, Huddinge, Salem and in other neighbourhoods of Stockholm in June 2008 and April 2009. The situation in these areas, in which many Iraqis are concentrated, demonstrates the limited effectiveness of family- and community-based networks. On the one hand, thousands of Iraqis have managed to migrate to Sweden, where on arrival many have been supported by religious and/or family networks. On the other, most families are still scattered across different countries and family reunification seems difficult to achieve. The presence of Chaldaeans and Assyrians in Sweden since the mid-1970s, together with the development of religiousbased migrant organizations, contributes to the attractiveness of Sweden as a host country. Migration flows from northern Iraq have never stopped and continue to develop in response to the ongoing crisis in Iraq.

Migratory itineraries of Iraqis are complex and comprise several stages. Refugees are compelled to adopt strategies of adaptation that address the difficulties they meet during their journey. Most family members have been separated over more or less long periods - some are still separated. A 
young Iraqi Syriac ${ }^{4}$ woman I met in April 2009 in Sednaya - a town 40 kilometres North of Damascus, is now living with her father-in-law and her two young children, having left Mosul a few weeks earlier. Her husband had left Iraq in 2005 and went to Sweden via Turkey. As she was pregnant with their second child she was not able to follow him but decided to wait for the opportunity for formal family reunification. But in October 2008 attacks against Iraqi Christians intensified and she had to leave Iraq hurriedly to find asylum in Syria, where she is waiting to join her husband in Sweden. There are many such narratives of family divided by war but also by the restrictive asylum policies of most of the main host countries. Certain families like that of this young Iraqi interviewed in Stockholm in April 2009 have been separated for several years because of the evolution of the Iraqi conflict and because of immigration rules that differentiate between minors and older children, with the result that families are split:

I was born in Baghdad in 1978, my family is native of Dohuk in the North of Iraq. My father was a taxi driver. I have two sisters and two brothers. At the beginning of 1980s, members of my family left Iraq towards Germany, France and Canada, to avoid conscription and escape difficulties connected to the war. At the beginning of 1990s, my father wanted to leave, but he gave up when the situation improved in Bagdad, and we saw people in refugee camps in difficult situations. We were all young people in the family, my father thus decided to stay in Bagdad.

I left Iraq during the summer 2006. I stayed one month in Syria, in Jaramana [a southern suburb of Damascus]. All my family lives today in Canada. My parents and my two younger brothers made a request of immigration for Canada since Iraq, they obtained the immigration in 2005. They went to Jordan to finish the procedure with the Canadian embassy and they left. My sister and I remained in Iraq, we were both adults at the time of the request, we were not thus accepted, and we had to make an individual request. We thus stayed in Bagdad. We made a request of family reunification, but it takes time. Meanwhile, we received threats in which we were asked to leave our house. I had a small store of photography, it was destroyed. One week later they attacked our house. We ran away towards Syria. We had relatives who were left to Damascus previously. They accommodated us a few nights then we rented an apartment in Jaramana. My parents helped us by sending us some money so that we can leave Syria. I appealed to a smuggler, and I was able to leave Syria with false papers. Each of us had to pay US\$10,000 to leave. We stayed only one month in Syria. There are two main reasons why I decided to go to Sweden. First I had relatives already living there. Second, and this is the main reason, it is that here I could have quickly a resident's permit. I did not want to stay without [a] paper.

We have been welcomed here by our paternal cousins. They have lived in Sweden since the end of 1970s; others arrived during the 1990s. I settled down with my sister in Södertälje, in the south suburbs of Stockholm. We are now well enough here, even if our family is in Canada. It is here, I think, that I am going to make my life, we shall see later if I join them, but I learnt the language, I work and I am

\footnotetext{
${ }^{4}$ A member of the Syriac Orthodox Church, of which there are small numbers in Iraq.
} 
soon going to get married here. For all these reasons I do not think of leaving Sweden.

Similar situations are found in Damascus, illustrated by the following examples that show the difficulty of reorganizing migratory networks when family links are disrupted:

- An Assyrian family that lives today in Damascus is in a very difficult economic and social situation. A young mother of two children left Iraq in 2006 after her husband, who was a photographer and possessed a store, had to stop his activity. They share their apartment with the parents of her husband. Three of her brothers are in Australia. They first left Iraq for Turkey and then Greece to go from there to Australia, where they asked for asylum. Recently arrived in Australia, they are not able to send money to their family in Damascus. They are trying to cope with their own resettlement and furthermore they have to reimburse the expenses generated by their emigration journey. The family in Damascus has to pay a 10,000 Syrian pounds (US\$200) rent a month. They manage thanks to the pension that the father-in-law of the interviewee, who resides in Syria, still receives and that is regularly sent to them from Iraq. Their family in Iraq also sends them basic food products, like rice, sent by taxis that connect Iraq to Damascus. Geographical dispersion of family members and the precariousness of their legal and economic situations results in the dislocation of family systems of solidarity. Strategies of survival have been established, with solidarity networks limited to meeting daily needs.

- A Chaldaean family, which also left Baghdad in 2006, lives today in part on money gathered from the sale of furniture and from savings brought from Iraq. Numerous members of their close family (uncle, aunt, cousin) have lived abroad (the United States, Australia, Canada, the United Kingdom and Denmark) since the early 1980s and the start of the war with Iran. They maintain rather distant relations with family abroad and do not seek to contact them to ask for assistance. Of three children, two sons work in the construction sector for 6000 Syrian pounds (US\$120) a month each; they have to pay 10,000 Syrian pounds (US\$200) rent each month. Their major anxiety today is the end of savings brought from Iraq that allows them to pay for everyday life. Income earned by the two sons hardly covers the monthly rent of their apartment. At the beginning of March 2007, the brother of the woman interviewed left Baghdad with his wife and came to Syria to join them in their two-room apartment. Their emigration request to Australia was refused and they are now waiting for the implementation of the UNHCR resettlement programme.

- Another Assyrian family from Baghdad arrived in 2006 and is now settled in Damascus in a three-room apartment rented for 8000 Syrian pounds (US\$160) a month. They had to stop work in Iraq because of security problems and decided to leave Baghdad. They live thanks to money sent to them by the father of the husband from Baghdad - around 15,000 Syrian pounds (US\$300) a month. They did not find a job in Syria. The woman interviewed was doing embroidery at 
home but preferred to stop because earnings were too low. They left Iraq after having sold all their possessions there. They arrived in Damascus without any relatives or contact in the city and were steered towards Jaramana by other Iraqis whom they met accidentally in the street and by their taxi driver. They knew that they had some close family living in Damascus but they did not know where they were living, having totally lost contact since their departure from Iraq . While attending the Assyrian mass the husband recognized his sister-inlaw and was able to reactivate the contact. Later, while standing on their balcony, they recognized their former neighbours from Baghdad. They knew that their neighbours left for Damascus without knowing where they were actually living. They have close family in Sweden, Australia and in the United States, but all having left since 2003, they are not in contact at the moment.

- Their neighbours, also an Assyrian family who came from Baghdad in 2004, are living in a three-room apartment they rent for 7500 Syrian pounds (US\$150) a month. They live thanks to the money brought from Baghdad and with income earned by the husband who works in a traditional fast-food job that he already had in Baghdad, for 250 Syrian pounds (US\$5) a day. They have relatives in Australia but their request for emigration has been refused.

\section{SYRIA, A STEP BEFORE RESETTLEMENT IN A THIRD COUNTRY}

For some Iraqis, Syria is only a step - a first country in which refugees find safety and try to pursue their itinerary towards a third country, where they can settle for the long term. This strategy of exile step by step is associated with the limited agendas of international organizations in Iraq, and the policy of neighbouring countries that do not offer permanent settlement, legal stay or access to employment. On arrival in Syria, refugees activate their family networks both locally and in the wider diaspora to obtain assistance and prepare for further movement. They settle down temporarily and precariously. Some try to emigrate illegally but most fail: many Iraqis lost large sums of money without being able to leave Syria. An Iraqi family interviewed in the suburb of Stockholm in April 2009 tells of their departure and the itinerary that led them to Sweden.

We are now six in the family: myself, my wife and our four children who currently live in Sweden. I am 56 years old and my children are between 10 and 26 years. Our fifth child was killed in Baghdad in 2006 when he was 20 years old. We used to live between Baghdad and Mosul. I was employed in the oil sector, my wife was a teacher. In spite of the embargo and the war, our economic situation was good. I had a good position, we owned our house and we had a car. My older sons studied at the university. My son who was killed was a student at the University of Baghdad. After the arrival of the Americans in Iraq, the situation deteriorated, we lived many difficult moments because of the troubles and the fear. I had to move in various regions of Iraq for my work. I often went to Mosul and to Kirkuk. After 2003, it became risky to move because of the activity of the insurgents and the terrorist groups. These groups began to intimidate all the 
persons who worked for the State or for the Americans, especially the persons employed in key sectors such as the oil sector. They asked the employees to leave their work. We were working for Iraqi citizens and not for such-or-such a party or for the Americans. Nevertheless, I continued to work. At the end of 2005 and at the beginning of 2006, I received personal threats. As I am Christian I was perceived by those who where threatening me as being pro-American.

We were afraid of moving in the city, even in our own neighbourhood. After the death of my son I decided that we should leave all for Syria. I had put my children under cover the while I was preparing the passports. We left at the end of 2006 and we stayed there a year and three months. We left for Syria, because it was the only country to have opened its doors to us, and especially for the persons who are not rich. It is very difficult to enter Turkey or Jordan. Besides, the country is not expensive compared with the nearby countries. And then it is rather easy to obtain a resident's permit and to register his children in the school system. We had theimpression we would be treated like Syrian citizens and not as foreigners. We settled down in Jaramana, where many Iraqis live and where the accommodation was relatively cheaper. We had close relatives who had left before us. They helped us to settle in Damascus. We also received some money from our family who lives in Canada and Australia.

By leaving Iraq, we lost everything. First, we tried to emigrate illegally towards Europe but it did not work and we lost a lot of money. We thus stayed in Syria and we went to register at the UNHCR. We told them our story and we were rather quickly accepted to be resettled in Sweden. We would have preferred an English-speaking country to facilitate our integration in the labour market and especially that of our children who have already begun their university curriculum. We had made a request to emigrate to Canada where my sister has lived since the 1970s and to Australia where members of my family live - but we were refused. The Swedes noticed during our interview in Syria that we had many family members of my wife already in Sweden: I believe that it played in our favour.

\section{LIMITED ROLE OF RELIGIOUS NETWORKS}

Religious networks have only marginal effects in the present migration movement. Despite declarations from the Chaldaean church in Mosul asking Christians not to leave the country, violence against Christians in autumn 2008 led to the emigration of hundreds of Iraqis to Syria, Lebanon, Turkey and further abroad. Among my informants was a Chaldaean family that found asylum in the eastern suburbs of Beirut: they had tried to stay in Mosul as long as they could. The father had been working as a carpenter and despite waves of violence the family decided to stay because they were not targeted directly and also because they did not have the money to leave the country. In October 2008 they were directly threatened as Christians and decided to leave and seek refuge in villages around Mosul, where they have family members. After staying a while with their family they realized that it would be very difficult to find a job in this rural area. They then decided to spend the money they took with them to go to Beirut, having heard from a family member there 
that it was quite easy to find a job in Lebanon. They bought plane tickets from Erbil to Beirut. Upon arrival in Lebanon their relatives helped them to find an apartment and a job. They registered at the UNHCR to receive assistance and applied to be resettled in a third country. The Chaldaean church in Lebanon is a small organization: today it has more Iraqi refugees then Lebanese citizens in its parishes and provides very limited assistance to Iraqis.

Possibilities for Iraqi refugees to emigrate to a third country are very limited and, with the growing Iraqi presence, the proportion of families managing to move on from Arab states is low. The UNHCR obtained a plan of resettlement allowing 20,000 Iraqis to emigrate towards western countries in 2007 - but this was to cover all Iraqi refugees in the Middle East and represents a fraction of those displaced in the region ${ }^{5}$. A limited number of individuals re-emigrate to a second country like Lebanon, where one can find approximately 10,000 registered Iraqi refugees, or to Egypt, where more than 9000 registered Iraqi refugees are living in 2009 (Regional Response Plan for Iraqi Refugees, UNHCR 2010). A small number use diasporic networks and manage to emigrate by getting married to a partner who has obtained a residence permit in a western country and can bring his or her spouse through family reunification procedures. These practices are undertaken by only a minority of refugees, however. In the end, Syria appears as a dead end between return to Iraq (not a serious option for most refugees) or further migration to a third country - the clearly expressed wish of most of my informants.

\section{CONCLUSION: LOCAL FORMS OF 'INTEGRATION', SHORT-TERM COPING STRATEGY OR PATH TOWARDS LONG-TERM SETTLEMENT?}

There are very important differences between Iraqi refugees, which are associated with their socio-economic status in Iraq, the religious groups to which they belong, their current places of residence and their standards of living. Religious and kin groups are more or less numerous, more or less organized and have varying degrees of connection to diasporic networks. Families are usually scattered: family and community networks are fragmented, although this can preserve intra-familial coherence. Families and communities are engaged in intensive efforts to reorganize themselves in exile.

Many families are divided and live in several countries of exile in the Middle East and beyond. The period spent in Damascus does not constitute simply a waiting time but plays an important role in elaboration of the migra-tory project. Not all members of the same family have left Iraq at the same date. The family reunification process is formulated in Damascus, activating solidarity networks and facilitating settlement in the host country. Newcomers benefit by securing accommodation that they share with other members of their family and usually have less difficulty finding employment. They look forward to departure to a third country that will accept them, although the number of resettlements by the UNHCR remains rather low (around 22,600 between February 2007 and October 2010 - UNHCR 2010). Transnational migratory networks seem to play an important role

\footnotetext{
5 'Operationally, UNHCR envisages submitting 20,000 Iraqi refugees for resettlement by December 31, 2007 [...]. The figure of 20,000 compares with a total of 3,183 Iraqis resettled in the four year period 2003-2006' (UNHCR 2007c: 1).
} 
for some groups like the Christians or the Mandaeans who emigrate in large numbers from Iraq but my research suggests that in general their efficacy may be limited.

Refugees with temporary status can stay for very long periods in host states, as in the case of some Iraqis in Jordan or for the Sudanese in Lebanon. But well-established refugees like Palestinians in Kuwait or in Libya can be expelled en masse during regional political crises. Migrants in the Middle East are often subject to a rapid change in their situation and strong local integration (through economic participation for example) does not always mean integration in the long term. In fact, economic participation can lead to empowerment of refugees in the sense that it provides them with means to undertake further migration. The Palestinian case in Lebanon shows that emigration (or resettlement) depends on access to resources. Most Iraqi migrants belong to groups with some connection to the diaspora and to local society in host states. Here local integration can be understood as part of an exit strategy and as a necessary stage before further migration. 


\section{REFERENCES}

Al-Ali, Nadje (2007), 'Iraqi women in diasporic spaces: Political mobilization, gender and citizenship', Revue des mondes musulmans et de la Méditerranée, $\mathrm{n}^{\circ} 117-118$, pp. 137-153.

Al-Ali, Nadje, Black, Richard and Koser, Khalid (2001), 'Refugees and transnationalism: The experience of Bosnians and Eritreans in Europe', Journal of Ethnic and Migration Studies, 27: 4, pp. 615-34.

Black, Richard (2001), 'Fifty years of refugee studies: From theory to policy', International Migration Review, 35: 1, pp. 57-78.

Boyd, Monica (1989), 'Family and personal networks in international migration: Recent developments and new agendas', International Migration Review, 23: 87, pp. 638-69.

Chatelard, Géraldine (2003), 'Iraqi forced migrants in Jordan. Conditions, religious networks, and the smuggling process', WIDER, Discussion Paper No. 2003/34, United Nations University, Helsinki.

Choldin, Harvey M. (1973), 'Kinship networks in the migration process', International Migration Review, 7: 2, pp. 163-75.

Danis, Didem A. (2006), 'Waiting on the purgatory, religious networks of Iraqi Christian transit migrants in Istanbul', EUI Working Papers, RSCAS n 2006/25, http://cadmus.eui.eu/bitstream/handle/1814/6228/\%20RSCAS_2006_25.pdf? sequence=1 Accessed 7 March 2011.

Durand, Marie-Françoise (1994), 'Entre territoires et réseaux' Between territories and networks, in Bertrand Badie and Catherine Wihtol de Wenden (eds), Le défi migratoire. Questions de relations internationales The migratory challenge. Questions of international relations, Paris: Presses de la Fondation Nationale des Sciences Politiques, pp. 141-57.

Faist, Thomas (2000), The Volume and Dynamics of International Migration and Transnational Social Spaces, Oxford: Clarendon Press.

Fawcett, James T. (1989), 'Networks, linkages, and migration systems', International Migration Review, 23: 3, pp. 671-80.

Frontiers Association (2006), 'Annual report. Refugee and migrant protection in Lebanon in 2006', Frontiers Association, Beirut.

Gurak, Douglas T. and Caces, Fe (1992), 'Migration networks and the shaping of migration systems', in Mary M. Kritz, Lin Lean Leam and Hania Zlotnik (eds), International Migration Systems. A Global Approach, New York: Oxford University Press, pp. 150-76.

Hansen, Art (1981), 'Refugee dynamics: Angolans in Zambia 1966 to 1972', International Migration Review, 15: 1/2, pp. 175-94.

International Crisis Group (2008), 'Failed responsibility: Iraqi refugees in Syria, Jordan and Lebanon', Middle East Report No. 77, p. 16, http://www.crisisgroup.org/en/regions/middle-east-north-africa/iraq-iran-gulf/iraq/077-fail 
ed-responsibility-iraqi-refugees-in-syria-jordan-and-lebanon.aspx. Accessed 7 March 2011.

Jacobsen, K. (2006), 'Editorial introduction. Refugees and asylum seekers in urban areas: A livelihoods perspective', Journal of Refugee Studies, 19: 3, pp. 273-286.

Katuszewski, Jacques and Ogien, Ruwen (1981), Réseaux d'immigrés. Ethnographie de nulle part Immigrants' networks. Ethnography of nowhere, Paris: Les éditions ouvrières (coll. Politique et sociale).

Koser, Khalid (2002), 'From refugees to transnational communities?', in Nadje Al-Ali and Khalid Koser (eds), New Approaches to Migration? Transnational Communities and the Transformation of Home, London and New York: Routledge, pp. 138-52.

Kritz, Mary M. and Zlotnik, Hania (1992), 'Global interactions: Migration systems, processes, and policies', in Mary M. Kritz, Lin Lean Leam and Hania Zlotnik (eds), International Migration Systems. A Global Approach, New York: Oxford University Press, pp. 177-89.

Kunz, Egon F. (1973), 'The refugee in flight: Kinetic models and forms of displacement', International Migration Review, 7: 2, pp. 125-46.

(1981), 'Exile and resettlement: Refugee theory', International Migration Review, 15: 1/2, pp. 42-51.

Leenders, R. (2008), 'L'adieu aux armes: la politique des réfugiés irakiens et son impact sécuritaire sur la région' A Farewell to Arms: the politics of Iraqi refugees and its security impact on the region, Maghreb-Machrek, 198, pp. 93-122.

Light, Ivan (1993), 'Migration networks and immigrant entrepreneurship', in I. Light (ed.), Immigration and Intrepreneurship: Culture, Capital and Ethnic Networks, New Brunswick: Transaction Publishers, pp. 25-49.

Loescher, Gil (1990), 'Introduction: Refugee issues in international relations', in Gil Loescher and Laila Monahan (eds), Refugees in International Relations, Oxford: Clarendon Press, pp. $1-33$.

Ma Mung, E., Doraï, M. K., Loyer, F. and Hily, M. (1998), 'La circulation migratoire' Migratory circulation, Migrations études, 84, Décembre, p. 12. http://halshs.archives-ouvertes.fr/halshs-00673697

Marx, Emmanuel (1990), 'The social world of refugees: A conceptual framework', Journal of Refugee Studies, 3: 3, pp. 189-203.

Massey, Douglas S. Joaquin Arango, Graeme Hugo, Ali Kouauci, Adela Pellegrino and Edward Taylor (1993), 'Theories of international migration: A review and appraisal', Population and Development Review, 19: 3, pp. 431-66.

Montagne, Robert (1954), 'Etude sociologique de la migration des travailleurs musulmans d'Algérie en France. Cahier liminaire', in Robert Montagne (ed.), Etude sociologique de la migration des travailleurs musulmans d'Algérie en France, Cahier liminaire, Paris: Ministère de l'Intérieur, pp. 3-33.

Richmond, Anthony H. (1994), Global Apartheid. Refugees, Racism, and the New World Order, Toronto, New York and Oxford: Oxford University Press.

Simon, Gildas (2000), 'Le concept de champ migratoire' The concept of migra-tory field, in Table ronde GEOFORUM: Champs migratoires et structures urbaines, Aix-en-Provence, 26-27 Mai 2000.

Simon, Julien (2006), 'Irregular transit migration in the mediterranean: Facts, figures and insights', in N. Sørensen (ed.), Mediterranean Transit Migration, Copenhagen: Danish Institute for International Studies, pp. 25-65. 
Shami, Seteney (1996), 'Transnationalism and refugee studies: Rethinking forced migration and identity in the Middle East', Journal of Refugee Studies, 9: 1, pp. 3-26.

Smith, Michael Peter (2002), 'Preface', in Nadje Al-Ali and Khalid Koser (eds), New Approaches to Migration? Transnational Communities and the Transformation of Home, London and New York: Routledge, pp. xi-xv.

UN News Center (2007), 'Iraqis prevented from entering Syria by new visa rules, UN refugee agency says', 11 September, UN News Center.

UNHCR (2003), Preliminary Repatriation and Reintegration Plan for Iraq, Geneva: UNHCR.

— (2006), Assessment on the Situation of Iraqi Refugees in Syria, Geneva: UNHCR.

_ (2007a), Syria: UNHCR Advocating for Increased Bilateral Aid and 'Humanitarian Visas' for Iraqi Refugees, Geneva: UNHCR.

— (2007b), Syria Assures UN It Will Not Forcibly Deport Iraqi Refugees Under New Visa System, Geneva: UNHCR.

- (2007c), Resettlement of Iraqi Refugees, Geneva: UNHCR.

- (2010), UNHCR Syria Update, Geneva: UNHCR.

Van Hear, Nicholas (2006), 'Refugees in diaspora: From durable solutions to transnational relations', Refuge, 23: 1, pp. 9-15.

Wahlbeck, Östen (2002), 'The concept of diaspora as an analytical tool in the study of refugee communities', Journal of Ethnic and Migration Studies, 28: 2, April, pp. 221-38.

Weiner, Myron (1993), 'Introduction: Security, stability and international migration', in Myron Weiner (ed.), International Migration and Security, Boulder: Westview Press, pp. 1-35. 